\title{
Preparation of zirconium oxide on silica and characterization by X-ray photoelectron spectroscopy, secondary ion mass spectrometry, temperature programmed oxidation and infra- red spectroscopy
}

\section{Citation for published version (APA):}

Meijers, A. C. Q. M., Jong, de, A. M., van Gruijthuijsen, L. M. P., \& Niemantsverdriet, J. W. (1991). Preparation of zirconium oxide on silica and characterization by X-ray photoelectron spectroscopy, secondary ion mass spectrometry, temperature programmed oxidation and infra-red spectroscopy. Applied Catalysis, 70(1), 53-71. https://doi.org/10.1016/S0166-9834(00)84154-8

DOI:

10.1016/S0166-9834(00)84154-8

Document status and date:

Published: 01/01/1991

\section{Document Version:}

Publisher's PDF, also known as Version of Record (includes final page, issue and volume numbers)

\section{Please check the document version of this publication:}

- A submitted manuscript is the version of the article upon submission and before peer-review. There can be important differences between the submitted version and the official published version of record. People interested in the research are advised to contact the author for the final version of the publication, or visit the $\mathrm{DOI}$ to the publisher's website.

- The final author version and the galley proof are versions of the publication after peer review.

- The final published version features the final layout of the paper including the volume, issue and page numbers.

Link to publication

\footnotetext{
General rights

- You may freely distribute the URL identifying the publication in the public portal. follow below link for the End User Agreement:

www.tue.nl/taverne

Take down policy

If you believe that this document breaches copyright please contact us at:

openaccess@tue.nl

providing details and we will investigate your claim.
}

Copyright and moral rights for the publications made accessible in the public portal are retained by the authors and/or other copyright owners and it is a condition of accessing publications that users recognise and abide by the legal requirements associated with these rights.

- Users may download and print one copy of any publication from the public portal for the purpose of private study or research.

- You may not further distribute the material or use it for any profit-making activity or commercial gain

If the publication is distributed under the terms of Article 25fa of the Dutch Copyright Act, indicated by the "Taverne" license above, please 


\title{
Preparation of zirconium oxide on silica and characterization by X-ray photoelectron spectroscopy, secondary ion mass spectrometry, temperature programmed oxidation and infra-red spectroscopy
}

\author{
A.C.Q.M. Meijers, A.M. de Jong, L.M.P. van Gruijthuijsen and J.W. \\ Niemantsverdriet* \\ Schuit Institute of Catalysis, Laboratory of Inorganic Chemistry and Catalysis, Eindhoven \\ University of Technology, $5600 \mathrm{MB}$ Eindhoven (Netherlands), tel. (+31-40) 473067, fax. ( +31 - \\ 40) 442576
}

(Received 26 June 1990, revised manuscript received 9 October 1990)

\begin{abstract}
Well dispersed $\mathrm{ZrO}_{2} / \mathrm{SiO}_{2}$ catalysts with a satisfactory thermal stability have been prepared by reaction between zirconium ethoxide dissolved in ethanol and hydroxyl groups of the silica support, followed by calcination in air at temperatures up to $700^{\circ} \mathrm{C}$. Characterization of the catalysts in intermediate stages of the preparation by secondary-ion mass spectrometry (SIMS), infra-red spectroscopy (IR) and temperature-programmed oxidation (TPO) gives a detailed picture of the formation of the $\mathrm{ZrO}_{2}$ from the ethoxide precursor. Intensity ratios of the zirconium and silicon X-ray photoelectron spectroscopy (XPS) signals have been used to estimate the dispersion of the catalysts and to investigate their thermal stability. The results obtained on the ethoxide-derived catalysts are compared with those on $\mathrm{ZrO}_{2} / \mathrm{SiO}_{2}$ catalysts prepared by incipient wetness impregnation from an aqueous solution of zirconium nitrate. The work illustrates how useful the combination of XPS, SIMS, IR and TPO is for investigating the genesis of catalysts.
\end{abstract}

Keywords: zirconium oxide/silica, catalyst preparation (precipitation), surface characterization, catalyst characterization (IR, SIMS, TPO, XPS).

\section{INTRODUCTION}

Zirconium oxide is a versatile catalyst which exhibits activity for a number of reactions, including hydrogenation [1], dehydrogenation, cracking, and the formation of alkenes from alcohols [2]. According to Tanabe and co-workers [3 and refs. therein, 4], $\mathrm{ZrO}_{2}$ surfaces possess both acidic and basic, as well as reducing and oxidizing properties.

Zirconium oxide is also of interest as a catalyst support. Highly dispersed zirconium oxide on silica appears particularly attractive because it combines the chemical properties of $\mathrm{ZrO}_{2}$ with the favourable mechanical stability of a 
$\mathrm{SiO}_{2}$ support $[5,6]$. The preparation of highly dispersed silica-supported zirconia forms the subject of this paper.

The simplest way to prepare $\mathrm{ZrO}_{2} / \mathrm{SiO}_{2}$ catalysts is by impregnating the silica until incipient wetness with an aqueous solution of zirconium nitrate, followed by calcination in air. As the results presented in this paper show, this procedure leads to large $\mathrm{ZrO}_{2}$ particles which leave most of the silica uncovered. However, a method in which the silica is contacted with a solution of zirconium ethoxide and acetic acid in ethanol, yields after calcination in air a well dispersed and thermally stable $\mathrm{ZrO}_{2}$, which covers the silica to a much greater extent.

The aim of this paper is to compare the two preparation methods by characterizing the catalysts in intermediate stages of the preparation with a combination of four techniques: X-ray photoelectron spectroscopy (XPS), secondary ion mass spectrometry (SIMS), infra-red spectroscopy (IR) and temperature-programmed oxidation (TPO).

\section{EXPERIMENTAL}

\section{Catalyst preparation}

The exchange preparation was carried out by adding $2 \mathrm{~g}$ of zirconium ethoxide (97\%, Aldrich), $1 \mathrm{ml}$ of concentrated acetic acid, and $5 \mathrm{~g}$ of silica (Grace 322 , surface area $=250 \mathrm{~m}^{2} / \mathrm{g}$ ) to $70 \mathrm{ml}$ of ethanol at room temperature. The mixture was stirred overnight and filtered afterwards. Next the filtrate was dried at $25^{\circ} \mathrm{C}$. The loading of this catalyst, determined by comparing the weight of this catalyst after calcination at $680^{\circ} \mathrm{C}$ with that of the untreated silica after calcination at $680^{\circ} \mathrm{C}$, was $16 \pm 0.5$ wt. $-\%$ of $\mathrm{ZrO}_{2}$. This catalyst was used for thermal stability studies with XPS. A second ethoxide-derived catalyst was made with an approximately five-fold diluted solution and had a loading of about $9 \pm 1.5 \mathrm{wt}$. $\% \mathrm{ZrO}_{2}$. This catalyst was used for SIMS, IR and TPO analysis.

The other $\mathrm{ZrO}_{2} / \mathrm{SiO}_{2}$ catalysts were made by adding dropwise an aqueous solution of $\mathrm{Zr}\left(\mathrm{NO}_{3}\right)_{4} \cdot 5 \mathrm{H}_{2} \mathrm{O}(\mathrm{BDH})$ to the silica until the incipient wetness point was reached. The catalyst was dried at room temperature for twenty-four hours and then at $110^{\circ} \mathrm{C}$. The zirconium loading of this sample was $8 \mathrm{wt.}-\%$ $\mathrm{ZrO}_{2}$. Samples with a loading of 16 and $24 \mathrm{wt} . \%$ were made by applying a second and a third impregnation step, as described above. Finally, a fourth nitrate-derived sample with a $\mathrm{ZrO}_{2}$ loading of $20 \mathrm{wt} . \%$ was made by a one-step incipient wetness impregnation. This sample was used for SIMS, IR and TPO analysis.

A model system was prepared in order to study the zirconia catalysts in XPS without charging complications [7]. The support consisted of a single-crystal silicon wafer covered by a thin (approximately $1 \mathrm{~nm}$ ) oxide layer. Zirconium was deposited on this wafer by adding the wafer to a solution of zirconium 
ethoxide in ethanol-acetic acid, heated to its boiling point. Next the wafer was dried in air at $50^{\circ} \mathrm{C}$.

\section{Characterization techniques}

XPS spectra were measured with a VG Escalab 200 equipped with a monochromatized Al X-ray source and a five-channel detector. All spectra were collected with the analyser at a pass energy of $50 \mathrm{eV}$. In order to minimize charging problems, samples were prepared by pressing catalyst powder in indium. Corrections for charging were made by using the Si $2 p$ XPS peak of the silica as an internal reference; all binding energies are reported with respect to the $\mathrm{Si} 2 \mathrm{p}$ peak at $103.4 \mathrm{eV}$.

SIMS spectra were measured with a Leybold SSM 200. We used a $5 \mathrm{keV}$ Ar + primary ion beam with a current density of $3 \mu \mathrm{A} / \mathrm{cm}^{2}$. The samples were pressed into indium pellets. Charge compensation was not employed.

Infrared spectra were recorded with a Hitachi 270-30 dispersive spectrometer with a resolution of $2 \mathrm{~cm}^{-1}$. Samples were prepared by pressing a mixture containing $200 \mathrm{mg}$ of $\mathrm{KBr}$ and $1 \mathrm{mg}$ of catalyst into a self supporting wafer.

TPO experiments were carried out with $200 \mathrm{mg}$ of freshly dried catalyst in a reactor which was heated to $500^{\circ} \mathrm{C}$ at a rate of $3^{\circ} \mathrm{C} / \mathrm{min}$. We used a $5 \%$ oxygen in helium flow of $7.5 \mathrm{ml} / \mathrm{min}$. The gases were analysed with a Leybold mass spectrometer (Quadruvac PGA 100) which could record up to 8 masses quasi-simultaneously.

\section{RESULTS}

\section{$X$-ray photoelectron spectroscopy}

As silica-supported zirconia is an insulator, its XPS spectrum is affected by charging. This is illustrated in Fig. 1, where XPS spectra are compared, in the range between 150 and $200 \mathrm{eV}$, of a $\mathrm{ZrO}_{2} / \mathrm{SiO}_{2}$ catalyst and an electrically conducting model system. The spectrum of the real catalyst shows a single broad $\mathrm{Si} 2 \mathrm{~s}$ peak at about $166 \mathrm{eV}$ and a poorly resolved $\mathrm{Zr} 3 \mathrm{~d}$ doublet with the $3 \mathrm{~d}_{5 / 2}$ component at about $195 \mathrm{eV}$. The expected values for $\mathrm{Si} 2 \mathrm{~s}$ of $\mathrm{SiO}_{2}$ and $\mathrm{Zr}$ $3 \mathrm{~d}_{5 / 2}$, however, are about $12 \mathrm{eV}$ lower, 154 and $182.4 \mathrm{eV}$ [8], respectively. Charge shifts observed in the XPS spectra of the other $\mathrm{ZrO}_{2} / \mathrm{SiO}_{2}$ samples ranged from 8 to $25 \mathrm{eV}$, depending on the amount of catalyst powder present on the indium sample holder. Charging was considerably more severe in reference samples of pure zirconium ethoxide, nitrate and oxide, from which XPS spectra could not be obtained at all.

The XPS spectrum of a conducting $\mathrm{ZrO}_{2} / \mathrm{SiO}_{2} / \mathrm{Si}$ model catalyst, on the other hand (Fig. 1), exhibits a sharp and well resolved $\mathrm{Zr}$ (3d) doublet with a $\mathrm{Zr} 3 \mathrm{~d}_{5 / 2}$ binding energy of $183.4 \mathrm{eV}$, a Si $2 \mathrm{~s}$ peak for the oxide layer at $155 \mathrm{eV}$ 


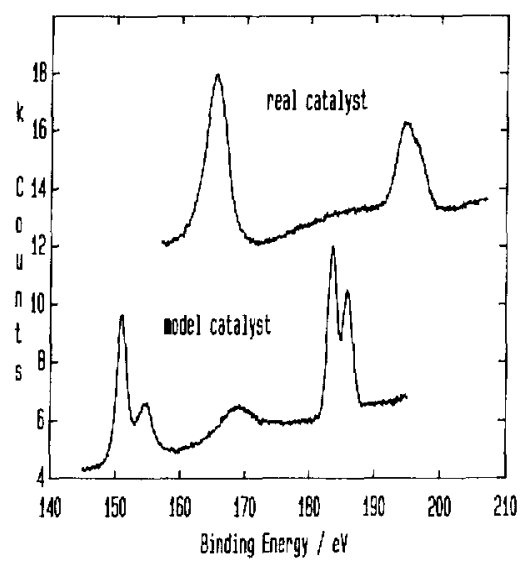

Fig. 1. XPS spectra in the range of the $\mathrm{Si} 2 \mathrm{~s}$ and $\mathrm{Zr} 3 \mathrm{~d}$ peaks of a real $\mathrm{ZrO}_{2} / \mathrm{SiO}_{2}$ catalyst (top) and of a conducting $\mathrm{ZrO}_{2} / \mathrm{SiO}_{2} / \mathrm{Si}(100)$ model catalyst (bottom), showing the effect of electrical charging. The spectrum of the real catalyst exhibits a charge shift of about $11 \mathrm{eV}$ and is severely broadened in comparison to that of the model catalyst. Note that the spectrum of the latter contains two $\mathrm{Si} 2 \mathrm{~s}$ peaks, one at about $151 \mathrm{eV}$ for zero-valent silicon from the substrate and the other at about $154.5 \mathrm{eV}$ for $\mathrm{Si}^{4+}$ from the $1 \mathrm{~nm} \mathrm{SiO}_{2}$ layer.

as well as one at $151 \mathrm{eV}$ for the semi-conducting silica substrate. In this case the charge shift of both the $\mathrm{ZrO}_{2}$ and the $\mathrm{SiO}_{2}$ amounts to $1 \mathrm{eV}$ only [7].

The rather large charge shifts observed in the spectra of the insulating samples are caused by the use of a monochromatic XPS. Here the X-ray source is at a large distance from the sample, and hence secondary electrons and Auger electrons from the source, which compensate to some extent for charging in standard XPS instruments, do not reach the sample.

XPS spectra were measured of the 8,16 and 24 wt.- $\% \mathrm{ZrO}_{2} / \mathrm{SiO}_{2}$ catalysts prepared from zirconium nitrate and the $16 \mathrm{wt} . \%$ catalyst from ethoxide, as a function of calcination temperature. All spectra yielded a $\mathrm{Zr} 3 \mathrm{~d}_{5 / 2}$ binding energy in the range $182.5 \pm 0.5 \mathrm{eV}$, which indicates that zirconium is present in the $4+$ oxidation state. $O 1$ s spectra showed one broad peak at a corrected binding energy of $532.3 \pm 0.3 \mathrm{eV}$. A weak $\mathrm{N}$ 1s signal with a binding energy of $407.3 \mathrm{eV}$, consistent with the presence of nitrate [8], was observed in the impregnated catalysts after drying at 110 and $200^{\circ} \mathrm{C}$. The intensities are shown in Table 1. The spectra of the catalysts from ethoxide showed a broad $\mathrm{C} 1 \mathrm{~s}$ signal at a binding energy of $284.5 \mathrm{eV}$. Contributions at higher binding energies which would be characteristic of ethoxide could not be detected due to a poor signal to noise ratio. The intensity of the $\mathrm{C} 1 \mathrm{~s}$ signal is given in Table 2 . The data indicate that catalysts calcined at $320^{\circ} \mathrm{C}$ and higher contain significantly less carbon than those calcined at lower temperatures.

Fig. 2 shows XPS spectra of the $\mathrm{ZrO}_{2} / \mathrm{SiO}_{2}$ catalysts after calcination in air 


\section{TABLE 1}

Intensity ratio of the $\mathrm{N} 1 \mathrm{~s}$ and $\mathrm{Si} 2 \mathrm{~s}$ peaks in the XPS spectra of the $\mathrm{ZrO}_{2} / \mathrm{SiO}_{2}$ catalysts prepared from zirconium nitrate for two calcination temperatures

\begin{tabular}{lll}
\hline $\begin{array}{l}\text { Loading } \\
\text { (wt. } \%)\end{array}$ & \multicolumn{2}{c}{$\mathrm{N} 1 \mathrm{~s} / \mathrm{Si} 2 \mathrm{~s}$} \\
\cline { 2 - 3 } & $110^{\circ} \mathrm{C}$ & $200^{\circ} \mathrm{C}$ \\
\hline 8 & $3.9 \cdot 10^{-2}$ & $1 \cdot 10^{-2}$ \\
16 & $7.2 \cdot 10^{-2}$ & $2 \cdot 10^{-2}$ \\
24 & $12.0 \cdot 10^{-2}$ & $5 \cdot 10^{-2}$ \\
\hline
\end{tabular}

TABLE 2

Intensity ratio of the $\mathrm{C} 1 \mathrm{~s}$ and $\mathrm{Si} 2 \mathrm{~s}$ peaks in the XPS spectra of the 16 wt.- $\% \mathrm{ZrO}_{2} / \mathrm{SiO}_{2}$ catalysts prepared from zirconium ethoxide as a function of calcination temperature

\begin{tabular}{ll}
\hline $\begin{array}{l}\text { Calcination temperature } \\
\left({ }^{\circ} \mathrm{C}\right)\end{array}$ & $\mathrm{C} 1 \mathrm{~s} / \mathrm{Si} 2 \mathrm{~s}$ \\
\hline 25 & $0.9 \pm 0.15$ \\
200 & $0.4 \pm 0.10$ \\
320 & $0.16 \pm 0.07$ \\
410 & $0.11 \pm 0.05$ \\
490 & $0.12 \pm 0.06$ \\
615 & $0.22 \pm 0.08$ \\
680 & $0.16 \pm 0.07$ \\
\hline
\end{tabular}

at $700^{\circ} \mathrm{C}$. All spectra were corrected for charging by positioning the Si $2 \mathrm{~s}$ peak at a binding energy of $154 \mathrm{eV}$.

The intensity of the zirconium signal relative to that of silicon is determined by the $\mathrm{ZrO}_{2}$ content of the catalyst and by its dispersion over the silica. For the three catalysts prepared from nitrate, Fig. 2 shows that, as expected, the zirconium intensity goes up as the $\mathrm{ZrO}_{2}$ loading increases. Note however, that the $\mathrm{Zr} 3 \mathrm{~d}$ intensity of the catalyst prepared from zirconium ethoxide is significantly larger than that of the nitrate-derived catalyst with the same $\mathrm{ZrO}_{2}$ loading. This forms evidence that the dispersion of the catalyst from ethoxide is higher than that of the conventionally impregnated catalysts.

Zirconium-to-silicon XPS intensity ratios for the four catalysts treated at a number of calcination temperatures are given in Fig. 3. The zirconium-to-silicon ratio of the catalyst from ethoxide decreases from about 1.1 for the freshly dried catalyst to about 1.0 for the catalysts calcined at around $700^{\circ} \mathrm{C}$. The weak dependence of the zirconium-to-silicon intensity ratio on the calcination temperature indicates that the catalysts are rather stable with respect to sintering.

The $\mathrm{ZrO}_{2} / \mathrm{SiO}_{2}$ catalyst with the same loading but prepared by incipient wetness impregnation exhibits not only a lower dispersion but also a lower 


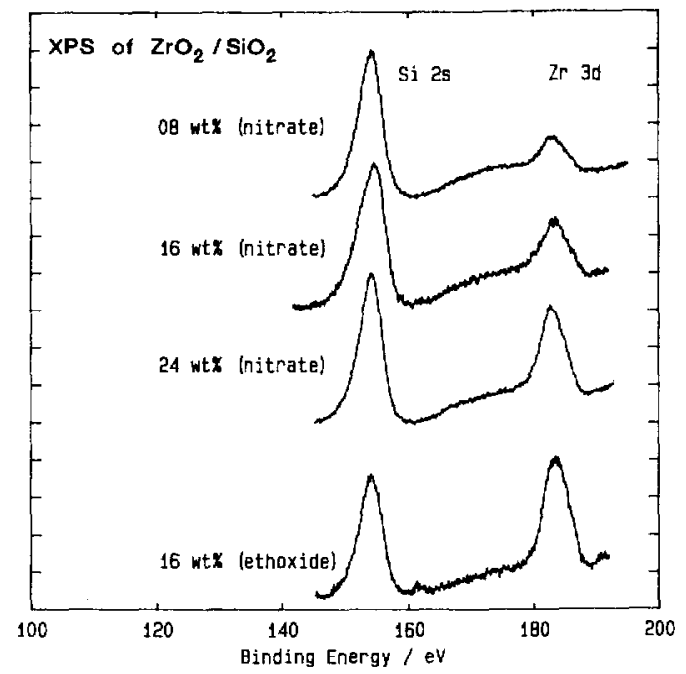

Fig. 2. XPS spectra in the range from 150 to $200 \mathrm{eV}$, showing the $\mathrm{Zr} 3 \mathrm{~d}$ and $\mathrm{Si} 2 \mathrm{~s}$ peaks of the $\mathrm{ZrO}_{2} / \mathrm{SiO}_{2}$ catalysts after calcination at $700^{\circ} \mathrm{C}$. All XPS spectra have been corrected for electrical charging by positioning the $\mathrm{Si} 2 \mathrm{~s}$ peak at $154 \mathrm{eV}$. The spectra labelled 'nitrate' correspond to the catalysts prepared by incipient wetness impregnation with an aqueous solution of zirconium nitrate, the spectrum labelled 'ethoxide' to that prepared by contacting the support with a solution of zirconium ethoxide and acetic acid in ethanol. The latter preparation leads to a better $\mathrm{ZrO}_{2}$ dispersion over the $\mathrm{SiO}_{2}$ than the standard incipient wetness preparation does, as is evidenced by the high $\mathrm{Zr} 3 \mathrm{~d}$ intensity of the bottom spectrum.

thermal stability, as Fig. 3 shows. The catalyst with the highest loading, $24 \mathrm{wt}$. $\%$, shows the largest decrease in zirconium-to-silicon ratio, whereas the ratio of the catalyst with $8 \mathrm{wt} . \% \mathrm{ZrO}_{2}$ loading is almost constant. We further note that the most significant loss of dispersion occurs at calcination temperatures between 25 and $400^{\circ} \mathrm{C}$.

In order to interpret the zirconium-to-silicon ratios quantitatively, we have used the model published by Kuipers et al. [9]. These authors showed that for randomly oriented samples a unique relationship exists between the XPS intensity ratio of the supported phase and the support on one hand and the dispersion of the supported phase on the other. Hence, the zirconium-to-silicon ratios of Fig. 3 can be converted to dispersions, and to characteristic dimensions of some likely particle geometries: layers with a uniform thickness $d$, spheres with a diameter $2 \mathrm{R}(=3 d)$ or half spheres with radius $r(=2.25 d)$. Table 3 summarizes these values for the catalysts which were calcined at $700^{\circ} \mathrm{C}$. Fig. 4 presents a highly schematic but instructive visualisation of what the calculated dispersions and support coverages mean if the $\mathrm{ZrO}_{2}$ particles were present in the form of half spheres.

To summarize, the XPS spectra clearly show that the ethoxide-derived $\mathrm{ZrO}_{2}$ / $\mathrm{SiO}_{2}$ catalyst is highly dispersed and exhibits a satisfactory thermal stability. 


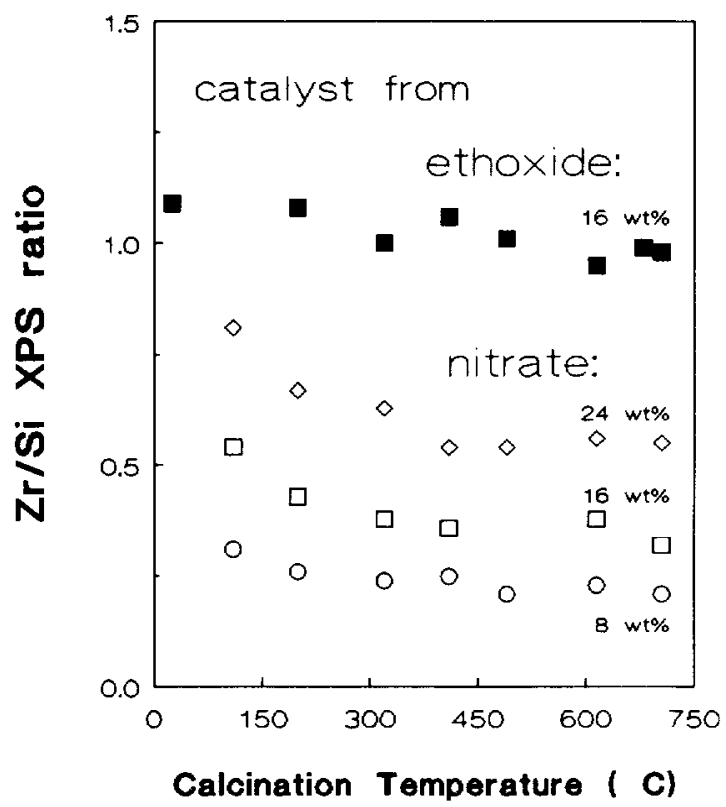

Fig. 3. $\mathrm{Zr}$ 3d/Si 2s intensity ratios calculated from the XPS spectra for the $\mathrm{ZrO}_{2} / \mathrm{SiO}_{2}$ catalysts prepared from ethoxide $(\boldsymbol{\square})$ and from nitrate: $(\diamond) 24 \mathrm{wt} . \%$; $(\square) 16 \mathrm{wt.} \%$; (O) 8 wt. $\%$ : as a function of calcination temperature.

\section{TABLE 3}

Dispersion and support coverage in $\mathrm{ZrO}_{2} / \mathrm{SiO}_{2}$ catalysts calcined at $700^{\circ} \mathrm{C}$ as derived from the $\mathrm{Zr}$ $3 \mathrm{~d} / \mathrm{Si}$ 2s XPS intensity ratios by means of Kuiper's model [9]

\begin{tabular}{|c|c|c|c|c|c|}
\hline $\begin{array}{l}\text { Loading } \\
\text { (wt.-\%) }\end{array}$ & $\mathrm{Zr} / \mathrm{Si}(\mathrm{XPS})$ & $\begin{array}{l}\text { Dispersion: D } \\
(\%)\end{array}$ & $\begin{array}{l}\Theta^{\alpha} \\
\left(\mathrm{m}^{2} / \mathrm{g}\right)\end{array}$ & $\begin{array}{l}\text { Effective layer } \\
\text { thickness: } d(\mathrm{~nm})\end{array}$ & $\begin{array}{l}r^{\beta} \\
(\mathrm{nm})\end{array}$ \\
\hline \multicolumn{6}{|c|}{ Catalysts from zirconium nitrate } \\
\hline 8 & $0.22 \pm 0.01$ & $12 \pm 1$ & 5 & 2.7 & 6.0 \\
\hline 16 & $0.37 \pm 0.04$ & $8 \pm 1$ & 7 & 4.2 & 9.5 \\
\hline 24 & $0.55 \pm 0.02$ & $7 \pm 0.5$ & 9 & 4.8 & 10.8 \\
\hline \multicolumn{6}{|c|}{ Catalyst from zirconium ethoxide } \\
\hline 16 & $1.0 \pm 0.05$ & $75 \pm 15$ & 67 & 0.42 & 0.95 \\
\hline
\end{tabular}

${ }^{\alpha}$ Area of silica covered by $\mathrm{ZrO}_{2}$; total support area is $250 \mathrm{~m}^{2} / \mathrm{g}$.

${ }^{\beta}$ Effective radius of a half spherical particle.

The $\mathrm{ZrO}_{2} / \mathrm{SiO}_{2}$ catalysts prepared from nitrate solution have a considerably lower dispersion. In both type of catalysts, zirconium is present in the $4+$ oxidation state irrespective of the calcination temperature. Nitrate residues 

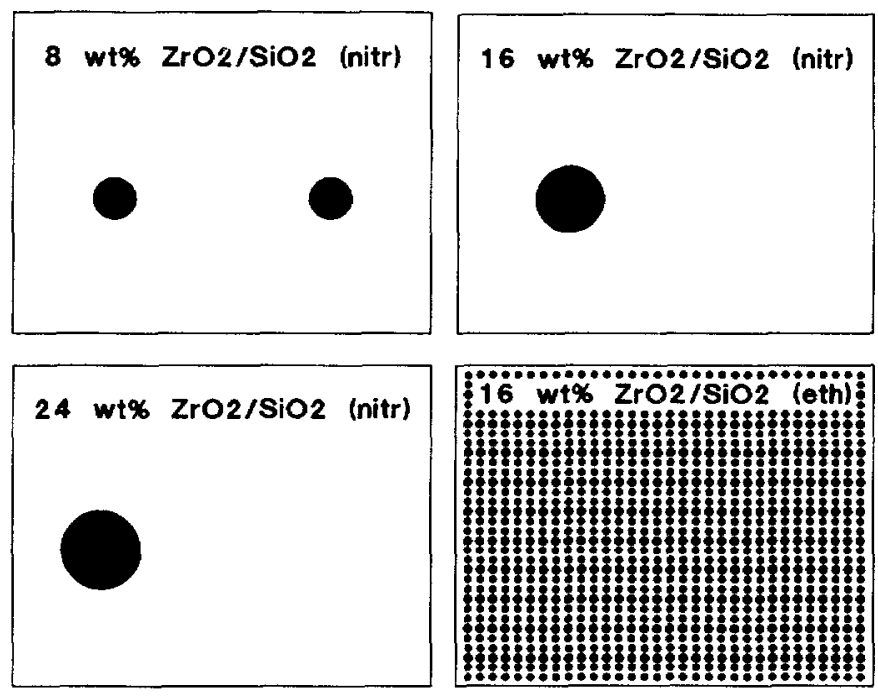

Fig. 4. Schematic representation of the dispersion of $\mathrm{ZrO}_{2}$ particles and the extent to which the silica support is covered in three $\mathrm{ZrO}_{2} / \mathrm{SiO}_{2}$ catalysts prepared by impregnation with an aqueous zirconium nitrate solution, and one prepared via an exchange reaction of the support with zirconium ethoxide. The rectangles represent $100 \mathrm{~nm}^{2}$ of silica support area, the circles represent a half-spherical particle of $\mathrm{ZrO}_{2}$ seen from above. See Table 3 for corresponding numbers.

can be observed in XPS spectra of samples calcined at temperatures up to $200^{\circ} \mathrm{C}$.

\section{Secondary ion mass spectrometry}

Fig. 5A shows a typical positive SIMS spectrum of a catalyst prepared from zirconium ethoxide. It contains peaks of $\mathrm{H}^{+}, \mathrm{C}^{+}, \mathrm{O}^{+}, \mathrm{Na}^{+}, \mathrm{Si}^{+}, \mathrm{K}^{+}, \mathrm{Ca}^{+}$, $\mathrm{SiO}^{+}, \mathrm{SiOH}^{+}, \mathrm{Zr}^{+}, \mathrm{ZrO}^{+}, \mathrm{In}^{+}$, and $\mathrm{ZrO}_{2}^{+}$. The relatively high intensities of sodium, potassium and calcium are a well-known artefact of SIMS; traces of

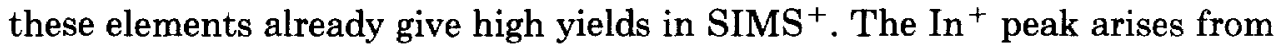
the indium foil in which the catalyst powder was pressed.

We found that the most useful SIMS information is in the relative intensities of the $\mathrm{Zr}^{+}, \mathrm{ZrO}^{+}, \mathrm{ZrOH}^{+}$and $\mathrm{ZrO}_{2}^{+}$ions. This is illustrated in Figs. 5B and $5 \mathrm{C}$ which show the isotopic pattern of these ions of a freshly dried (Fig. 5B) and a calcined (Fig. 5C) catalyst. Note that the SIMS spectrum of the freshly dried catalyst contains small but significant contributions of $\mathrm{ZrOH}^{+}$ ions. See for example the peaks at $107 \mathrm{amu}\left({ }^{90} \mathrm{ZrOH}^{+}\right.$and $\left.{ }^{91} \mathrm{ZrO}^{+}\right)$and 111 amu $\left({ }^{94} \mathrm{ZrOH}^{+}\right) . \mathrm{ZrOH}^{+}$is probably a fragment ion from zirconium ethoxide or acetate. In the sample which was calcined at $400^{\circ} \mathrm{C}$ the isotopic pattern of 

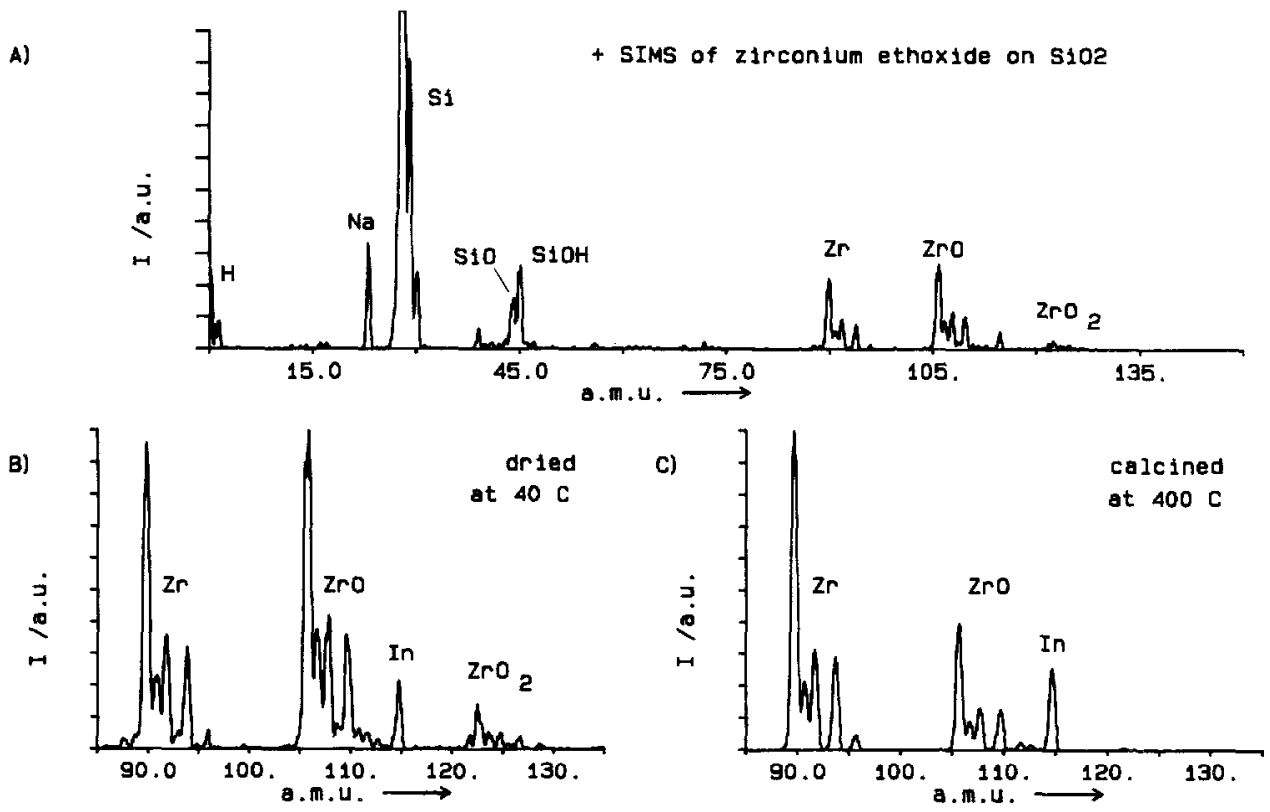

Fig. 5. Positive SIMS spectrum of the 9 wt. $-\% \mathrm{ZrO}_{2} / \mathrm{SiO}_{2}$ catalyst prepared from ethoxide, dried at $40^{\circ} \mathrm{C}(\mathrm{A})$, and two spectra of the $\mathrm{Zr}-\mathrm{ZrO}-\mathrm{ZrO}_{2}$ region for a dried catalyst (B) and a calcined one $(\mathrm{C})$.

$\mathrm{ZrO}$ resembles the pattern of $\mathrm{Zr}$, indicating that no more $\mathrm{ZrOH}$ species are present.

Fig. 6 contains the $\mathrm{ZrO}^{+} / \mathrm{Zr}^{+}$and $\mathrm{ZrO}_{2}^{+} / \mathrm{Zr}^{+}$ratios from the SIMS spectra for the ethoxide-derived catalysts as a function of calcination temperature. We also included these ratios for zirconium ethoxide and zirconium oxide reference samples. The figure clearly shows that catalysts prepared from zirconium ethoxide which were calcined below $200^{\circ} \mathrm{C}$ have $\mathrm{ZrO}^{+}$to $\mathrm{Zr}^{+}$and $\mathrm{ZrO}_{2}^{+}$to $\mathrm{Zr}^{+}$ ratios about equal to those of the zirconium ethoxide reference compound. However, samples calcined above $300^{\circ} \mathrm{C}$ have $\mathrm{ZrO}^{+}$to $\mathrm{Zr}^{+}$and $\mathrm{ZrO}_{2}^{+}$to $\mathrm{Zr}^{+}$ ratios which decrease towards those measured for $\mathrm{ZrO}_{2}$.

Hence, the SIMS spectra clearly indicate that the formation of $\mathrm{ZrO}_{2}$ in catalysts prepared by ion exchange from zirconium ethoxide occurs during calcination in air at temperatures between $300^{\circ} \mathrm{C}$ and $400^{\circ} \mathrm{C}$.

The SIMS spectra of the zirconium catalysts which were prepared by incipient wetness impregnation from a nitrate solution are of comparable quality to the spectra in Fig. 5. The spectrum of the freshly prepared sample dried at $40^{\circ} \mathrm{C}$ gives clear evidence that the zirconium species present on the silica surface is not $\mathrm{Zr}\left(\mathrm{NO}_{3}\right)_{4}$. Pure $\mathrm{Zr}\left(\mathrm{NO}_{3}\right)_{4}$ has a high $\mathrm{ZrO}^{+}$to $\mathrm{Zr}^{+}$ratio of about 2 (see Fig. 7). The ratio for the spectra of the fresh catalyst, however, is about 0.35 , which is more characteristic of zirconium oxide or, perhaps, hydroxide or 


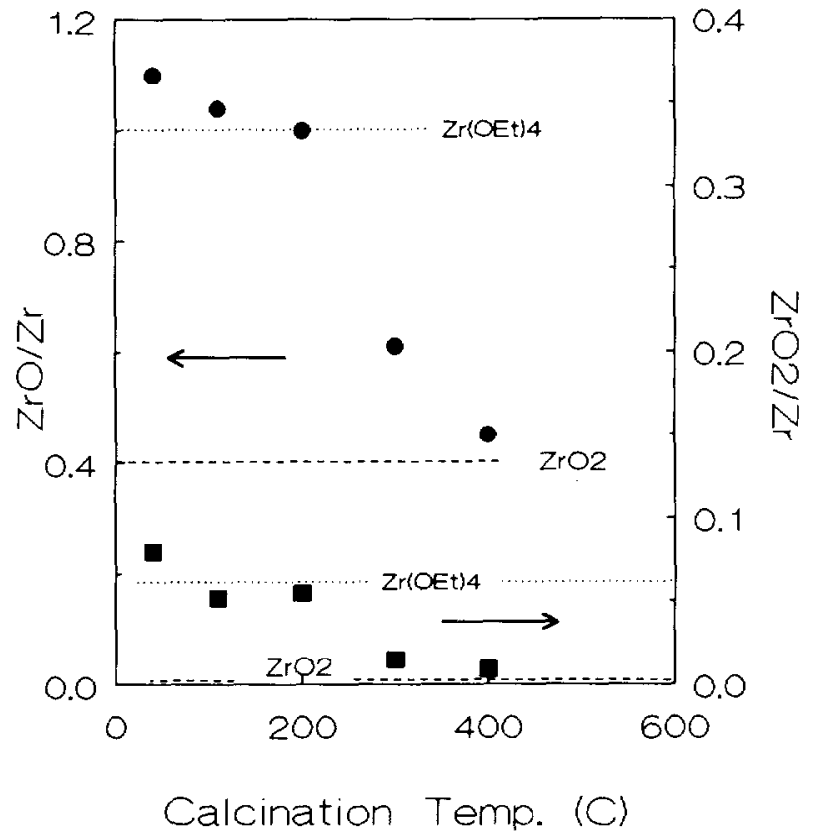

Fig. 6. SIMS ${ }^{+} \mathrm{ZrO}^{+}$to $\mathrm{Zr}^{+}$and $\mathrm{ZrO}_{2}^{+}$to $\mathrm{Zr}^{+}$ratios as a function of calcination temperature for a 9 wt. $\% \mathrm{ZrO}_{2} / \mathrm{SiO}_{2}$ catalyst prepared from zirconium ethoxide, along with the $\mathrm{ZrO}^{+}$to $\mathrm{Zr}^{+}$and $\mathrm{ZrO}_{2}^{+}$to $\mathrm{Zr}^{+}$ratios measured from zirconium ethoxide and zirconium oxide reference samples.

oxyhydroxide. The $\mathrm{ZrO}^{+}$to $\mathrm{Zr}^{+}$ratio increases at calcination temperatures above $400^{\circ} \mathrm{C}$ and finally drops back to the value characteristic of $\mathrm{ZrO}_{2}$. The $\mathrm{ZrO}^{+}$to $\mathrm{Zr}^{+}$of the zirconium nitrate reference sample decreases continuously with time spent in the vacuum system, which is probably caused by decomposition of the nitrate [10].

In negative SIMS the following species were observed: $\mathrm{C}^{-}, \mathrm{O}^{-}, \mathrm{OH}^{-}, \mathrm{H}_{2} \mathrm{O}^{-}$, $\mathrm{F}^{-}, \mathrm{C}_{2}^{-}, \mathrm{C}_{2} \mathrm{H}^{-}, \mathrm{C}_{2} \mathrm{H}_{2}^{-}, \mathrm{Si}^{-}, \mathrm{SiO}^{-}, \mathrm{SiOH}^{-}, \mathrm{SiO}_{2}^{-}, \mathrm{ZrO}^{-}$and $\mathrm{ZrO}_{2}^{-}$. Neither higher ethoxide fragments nor any nitrate fragments were found. A major problem is that a number of potentially interesting ions have the same masses, e.g. $\mathrm{SiO}^{-}$and $\mathrm{CO}_{2}^{-}$(mass 44) and $\mathrm{SiOH}^{-}$and $\mathrm{C}_{2} \mathrm{H}_{5} \mathrm{O}^{-}$(mass 45).

In summary, the SIMS measurements clearly reflect the transition from the precursor to $\mathrm{ZrO}_{2}$ in the catalysts prepared from ethoxide. Furthermore the spectra indicate that the zirconium species in the freshly prepared catalysts from nitrate solution is not a zirconium nitrate but a compound which already resembles an oxide, hydroxide or oxyhydroxide.

\section{Infrared spectroscopy}

In order to obtain more insight in the transformation of the precursor to zirconium oxide, the catalysts were studied with IR. A spectrum of each sample 


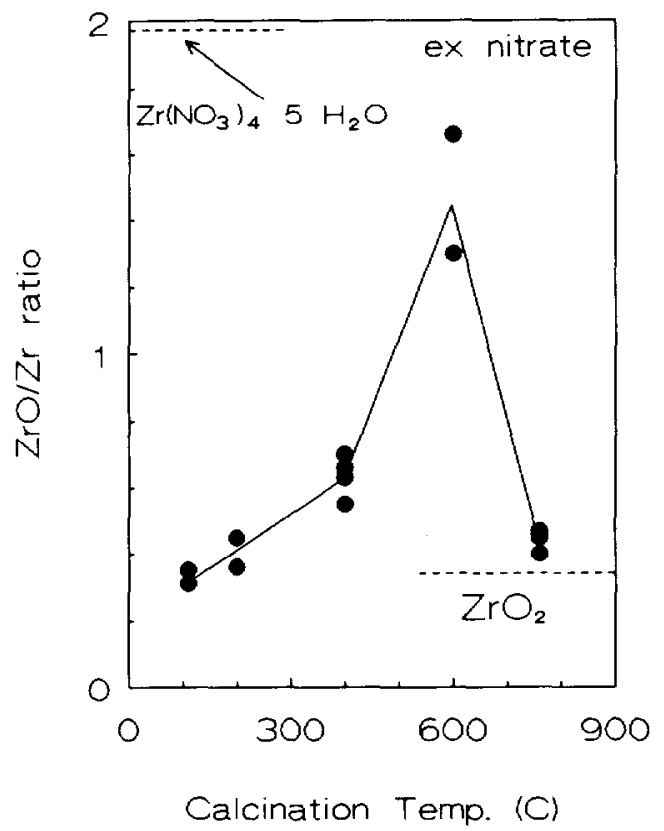

Fig. 7. SIMS ${ }^{+} \mathrm{ZrO}^{+}$to $\mathrm{Zr}^{+}$ratio for a $20 \mathrm{wt} . \% \mathrm{ZrO}_{2} / \mathrm{SiO}_{2}$ catalyst prepared by incipient wetness impregnation from an aqueous solution of zirconium nitrate. For comparison the $\mathrm{ZrO}^{+}$to $\mathrm{Zr}^{+}$ ratios of zirconium nitrate and zirconium oxide reference samples have been included.

was recorded in the range from 4000 to $400 \mathrm{~cm}^{-1}$. In addition, zirconium oxide, ethoxide and nitrate and silica spectra were recorded as references.

\section{Catalyst prepared from ethoxide}

Fig. 8 shows the infrared spectra of the catalyst prepared from zirconium ethoxide as well as those of $\mathrm{Zr}(\mathrm{OEt})_{4}$ and $\mathrm{ZrO}_{2}$ references, in the range of 1800 to $1200 \mathrm{~cm}^{-1}$. In the zirconium ethoxide reference spectrum peaks are visible at $1635 \mathrm{~cm}^{-1}(\mathrm{O}-\mathrm{H}$ bend $), 1590 \mathrm{~cm}^{-1}(\mathrm{COO}), 1475$ and $1430 \mathrm{~cm}^{-1}(\mathrm{C}-\mathrm{H}$ bend), and $1390 \mathrm{~cm}^{-1}(\mathrm{O}-\mathrm{H}$ bend $)$.

The IR spectrum of the freshly prepared catalyst, which was dried at $40^{\circ} \mathrm{C}$, differs from that of zirconium ethoxide in at least three points. First, the IR spectrum of the catalyst exhibits a broad band due to $\mathrm{Si}-\mathrm{O}$ between 1000 and $1300 \mathrm{~cm}^{-1}$. Second, the $\mathrm{O}-\mathrm{H}$ bending vibration at $1390 \mathrm{~cm}^{-1}$ is much weaker than in the zirconium ethoxide reference sample. Third, the spectrum of the catalyst contains an extra band at $1710 \mathrm{~cm}^{-1}$, characteristic of a $\mathrm{C}=0$ vibration. This band arises from the acetic acid we used to make the zirconium ethoxide more soluble. The assignment is confirmed by blank experiments in which we added acetic acid to a suspension of silica in ethanol and then filtrated and dried the silica. The same peak as above, at $1710 \mathrm{~cm}^{-1}$, was found, which we assign to acetate groups adsorbed on the silica surface. 


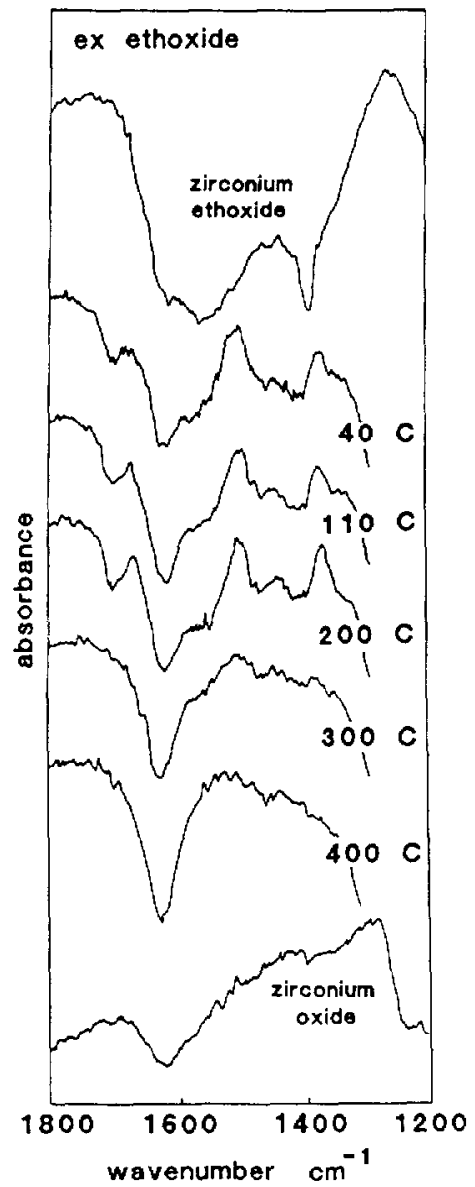

Fig. 8. Infra-red spectra in the range from 1200 to $1800 \mathrm{~cm}^{-1}$ as a function of calcination temperature for the $9 \mathrm{wt} .-\% \mathrm{ZrO}_{2} / \mathrm{SiO}_{2}$ catalyst prepared from ethoxide. Spectra for zirconium ethoxide and zirconium oxide references are also included.

With calcination temperature increasing to $200^{\circ} \mathrm{C}$ the spectrum basically does not change. However, after calcination at $300^{\circ} \mathrm{C}$ the $\mathrm{C}=\mathrm{O}$ band has disappeared and the $\mathrm{C}-\mathrm{H}$ bands have very much decreased in intensity. After calcination at $400^{\circ} \mathrm{C}$, no more organic species could be detected in the IR spectrum, and the spectrum resembled that of the $\mathrm{ZrO}_{2}$ reference sample.

\section{Catalyst prepared from nitrate}

Fig. 9 shows the IR spectra of the nitrate-derived catalyst calcined at different temperatures. Also included are the spectra of zirconium nitrate and zirconium oxide references. The IR spectrum of zirconium nitrate has peaks at $1610 \mathrm{~cm}^{-1}$ (O-H bending vibration), $1550 \mathrm{~cm}^{-1}$ (asymmetrical $\mathrm{NO}_{2}$ stretch- 


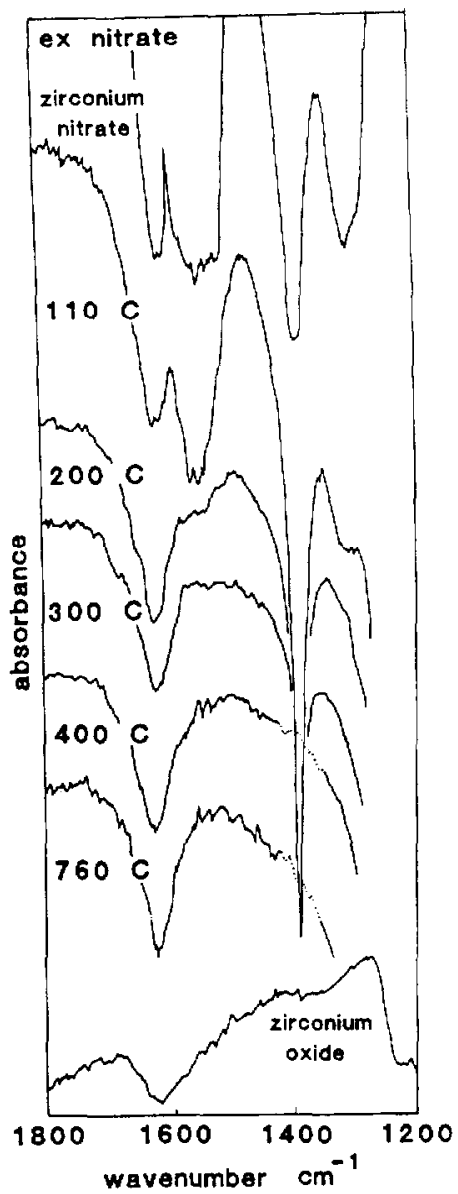

Fig. 9. Infra-red spectra in the range from 1200 to $1800 \mathrm{~cm}^{-1}$ as a function of calcination temperature for the $20 \mathrm{wt}$. $\% \mathrm{ZrO}_{2} / \mathrm{SiO}_{2}$ catalyst prepared from zirconium nitrate. Spectra for zirconium nitrate and zirconium oxide references are also included.

ing vibration $), 1310 \mathrm{~cm}^{-1}\left(\mathrm{NO}_{2}\right.$ stretching vibration $)$ and $\left(1400 \mathrm{~cm}^{-1}\right.$, symmetrical N-O stretching vibration) [11-14]. Such a combination of IR bands is characteristic for complexes in which the metal nitrate bonds have covalent character $[11,12]$. The last three have about equal intensity. These peaks are also present in the IR spectrum of the catalyst dried at $110^{\circ} \mathrm{C}$ but note that here the symmetric $\mathrm{N}-\mathrm{O}$ stretch at $1400 \mathrm{~cm}^{-1}$ is very intense. According to Gatehouse et al. [11,12], this band is characteristic of a purely ionically bound nitrate ion. In this case, the bands at 1550 and $1310 \mathrm{~cm}^{-1}$ are absent.

Thus, the IR spectra suggest that there are two nitrate species on freshly impregnated catalysts: one with a spectrum similar to that of the zirconium nitrate reference, which disappears after calcination between 100 and $200^{\circ} \mathrm{C}$, 
and the other with the IR spectrum of purely ionic nitrate, which disappears after calcination between 300 and $400^{\circ} \mathrm{C}$. We propose that the latter nitrate species form the counter ions of the silica support which is positively charged in solutions of low $\mathrm{pH}$.

In summary, the IR spectra of the ethoxide-derived catalyst clearly show the presence of acetate and ethoxide groups on samples calcined below $300^{\circ} \mathrm{C}$. These species disappear from the catalyst upon calcination at $300-400^{\circ} \mathrm{C}$. IR spectra of the nitrate-derived catalyst show that there are two nitrate species present after impregnation. Nitrate groups coordinated to zirconium decompose mainly below $200^{\circ} \mathrm{C}$ whereas nitrate groups on the silica support disappear after calcination at $300-400^{\circ} \mathrm{C}$.

\section{Temperature-programmed oxidation}

Temperature-programmed oxidation was carried out to monitor the evolution of products formed during calcination of the freshly prepared and dried catalysts. The spectra are shown in Fig. 10 for the ethoxide and Fig. 11 for the nitrate-derived catalyst. The TPO is not entirely conclusive because several masses cannot be assigned unambiguously. For example, mass 28 can be due to carbon monoxide, formed by incomplete oxidation of the zirconium ethoxide

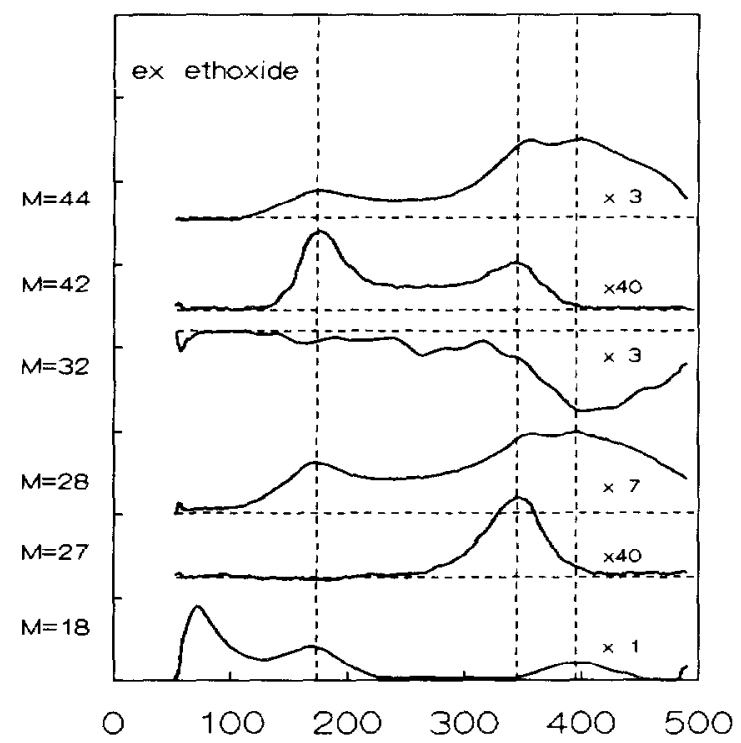

Temperature (C)

Fig. 10. TPO signals of the $9 \mathrm{wt} .-\% \mathrm{ZrO}_{2} / \mathrm{SiO}_{2}$ catalyst prepared from zirconium ethoxide showing the signals of mass $18(\times 1)$, mass $27(\times 40)$, mass $28(\times 7)$, mass $32(\times 3)$, mass $42(\times 40)$ and mass $44(\times 3)$. 


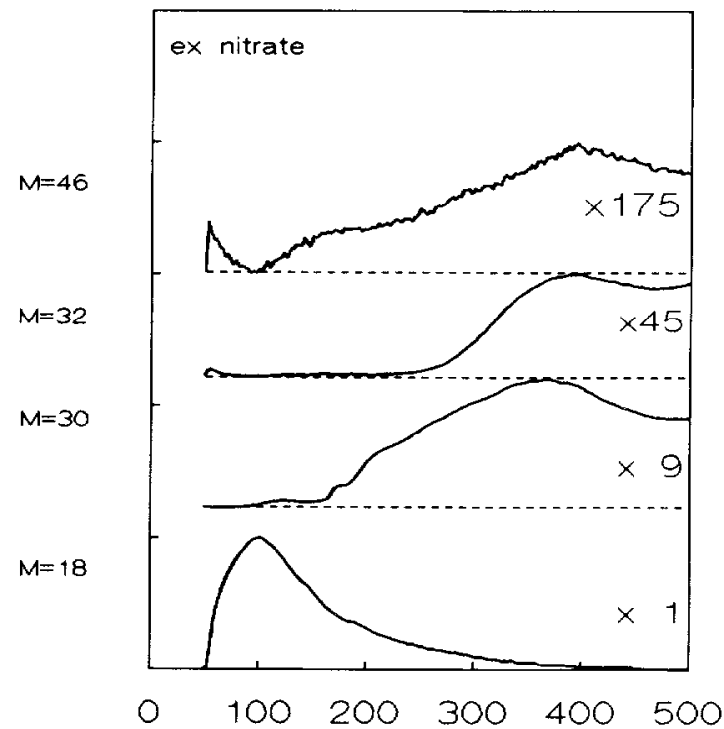

Temperature (C)

Fig. 11. TPO signals of the 20 wt. $-\% \mathrm{ZrO}_{2} / \mathrm{SiO}_{2}$ catalyst prepared from zirconium nitrate showing the signals of $\mathrm{H}_{2} \mathrm{O}(\times 1)$, $\mathrm{NO}(\times 9), \mathrm{O}_{2}(\times 45)$ and $\mathrm{NO}_{2}(\times 175)$.

precursor, but it can also be a fragmentation of the ethanol solvent. Similar considerations apply to other masses. Nevertheless, the spectra allow for a number of conclusions.

\section{Catalyst prepared from ethoxide}

The TPO curves consist of two regions, one with peaks in the range from 50 to $225^{\circ} \mathrm{C}$ when hardly any oxygen is consumed and an other from 275 to $500^{\circ} \mathrm{C}$. In order to attribute these signals we carried out some additional experiments. A solution of silica in ethanol was heated until all the ethanol had evaporated. The silica was dried at $40^{\circ} \mathrm{C}$ for three hours and a TPO experiment was carried out in the same way as described above. Small peaks were visible in the mass $18,28,42$ and 44 signals at $150^{\circ} \mathrm{C}$. These signals can all be assigned to adsorbed ethanol. The experiment was then repeated with acetic acid added to the solution. The same peaks were observed, only at a slightly higher temperature of $160^{\circ} \mathrm{C}$. Mass 31 (typical of ethanol) and mass 60 (typical of acetic acid) could not be detected in any of the TPO experiments. Hence, we assign the peaks in the region from 50 to $225^{\circ} \mathrm{C}$ to the desorption of ethanol and acetic acid from the solvent and water present on the silica.

The peaks above $275^{\circ} \mathrm{C}$ are then related to the zirconium ethoxide-acetate complexes on the support. At temperatures around $390^{\circ} \mathrm{C}$ oxygen consumption reaches a maximum and the products formed are characterized by masses 
18,28 and 44 . We attribute these peaks to the oxidation of carbonaceous species towards carbon dioxide and water and perhaps carbon monoxide. The maxima in these signals around $350^{\circ} \mathrm{C}$ are accompanied by maxima in those of mass 27 and 42 and can therefore be assigned to the decomposition of ethoxide-acetate.

\section{Catalyst prepared from nitrate}

Fig. 11 shows the signals of $\mathrm{H}_{2} \mathrm{O}$ (mass 18), $\mathrm{NO}(30), \mathrm{O}_{2}(32)$ and $\mathrm{NO}_{2}(46)$ in the TPO of the catalyst prepared from zirconium nitrate. Again at a low temperature we see desorption of water. Then starting at a temperature of $\pm 150^{\circ} \mathrm{C}$ until the end of the temperature scale $\mathrm{NO}$ and $\mathrm{NO}_{2}$ are evolving. Oxygen evolution starts at about $300^{\circ} \mathrm{C}$. These data are in agreement with data obtained by Gimblett et al. [15] on bulk $\mathrm{Zr}\left(\mathrm{NO}_{3}\right)_{4}$.

\section{DISCUSSION}

The most important difference between a $\mathrm{ZrO}_{2} / \mathrm{SiO}_{2}$ catalyst prepared via the ethoxide-hydroxyl reaction and one prepared by incipient wetness impregnation is the much higher dispersion of the former. This is clearly reflected by the zirconium-to-silicon XPS intensity ratios in Fig. 3 and the quantitative interpretation based on Kuiper's model [9] in Table 3. Although the dispersions in particular of the ethoxide-derived samples are sensitive to input parameters such as $\mathrm{ZrO}_{2}$ loading and support area, the values in Table 3 show that the characteristic linear dimensions of the $\mathrm{ZrO}_{2}$ particles originating from zirconium ethoxide are at least an order of magnitude smaller than in the catalysts derived from zirconium nitrate. Fig. 4 illustrates what this means in terms of particle size and coverage of the silica support. Hence we conclude that the $\mathrm{ZrO}_{2} / \mathrm{SiO}_{2}$ catalysts prepared via the ethoxide-hydroxyl reaction route are by far superior to the catalysts prepared via the standard incipient wetness impregnation technique.

Owing to the results from TPO, SIMS and IR we have a fairly detailed understanding of the way zirconium oxide forms on silica from the precursors. We propose that the following steps take place in the formation of $\mathrm{ZrO}_{2}$ from zirconium ethoxide on silica.

(1) In the solution of zirconium ethoxide and acetic acid in ethanol, ethoxide and acetate groups interchange following this mechanism:

$$
\mathrm{Zr}(\mathrm{OEt})_{4}+x \mathrm{CH}_{3} \mathrm{COOH} \longrightarrow \mathrm{Zr}(\mathrm{OEt})_{4-x}\left(\mathrm{CH}_{3} \mathrm{COO}\right)_{x}+x \mathrm{C}_{2} \mathrm{H}_{5} \mathrm{OH}
$$

This is a well-known reaction of metal alkoxides with organic acids and it increases the solubility of zirconium ethoxide. $x$ is small, typically 1 [16].

(2) When silica is added the following reaction takes place:

$$
\mathrm{Zr}(\mathrm{OEt})_{4-x}\left(\mathrm{CH}_{3} \mathrm{COO}\right)_{x}+\mathrm{Si}-\mathrm{OH} \longrightarrow \mathrm{Si}-\mathrm{O}-\mathrm{Zr}(\mathrm{OEt})_{p}\left(\mathrm{CH}_{3} \mathrm{COO}\right)_{q}
$$


The IR band at $1710 \mathrm{~cm}^{-1}$ gives evidence of the presence of the $\mathrm{CH}_{3} \mathrm{COO}^{-}$ ligand. Also, small amounts of ethanol and acetic acid adsorb on the silica surface.

(3) The TPO experiments indicate that water desorbs from the surface at about $50^{\circ} \mathrm{C}$ and that acetate and ethanol desorb around $175^{\circ} \mathrm{C}$.

(4) During calcination between $200^{\circ} \mathrm{C}$ and $300^{\circ} \mathrm{C}$, zirconium ethoxide ligands of the zirconium desorb as ethanol or decompose to leave carbonaceous residue on the surface and $\mathrm{ZrO}_{2}$ begins to form. This is concluded from the decreasing $\mathrm{ZrO}^{+}$to $\mathrm{Zr}^{+}$and $\mathrm{ZrO}_{2}^{+}$to $\mathrm{Zr}^{+}$ratios in SIMS, the decreasing intensity of the $\mathrm{C}-\mathrm{O}$ and $\mathrm{C}-\mathrm{H}$ vibrations in IR, and the decrease in carbon content as observed in XPS (Table 2). The TPO experiments suggest that the decomposition of ethoxide occurs at temperatures above $300^{\circ} \mathrm{C}$. We do not believe that this is in contradiction with the IR and SIMS results, because catalysts used in TPO experiments are necessarily treated differently than those used for IR and SIMS analysis: the latter were calcined for several hours, whereas in TPO a fresh sample was heated in situ at a rate of $3^{\circ} \mathrm{C} / \mathrm{min}$. Kinetic limitations are expected to shift features to higher temperatures.

(5) After calcination at $400^{\circ} \mathrm{C}$ the formation of $\mathrm{ZrO}_{2}$ is complete (SIMS) and almost all organic species have disappeared (IR). Carbonaceous residues are burned off with oxygen at temperatures between 350 and $500^{\circ} \mathrm{C}$ as follows from the TPO experiments.

In summary we can state that a zirconium ethoxide-acetate species reacts with the silica surface upon impregnation. At the same time acetate and ethanol adsorb on the surface. Upon calcination, these species desorb first. After calcination at $200-300^{\circ} \mathrm{C}$ ethoxide groups decompose and $\mathrm{ZrO}_{2}$ is formed. Finally the remaining carbon species are burned off between 350 and $500^{\circ} \mathrm{C}$.

The catalyst prepared from zirconium nitrate behaves quite differently. The SIMS spectra and in particular the $\mathrm{ZrO}^{+}$to $\mathrm{Zr}^{+}$ratios indicate that at least the majority of the phase deposited on the silica during impregnation is not zirconium nitrate but probably zirconium hydroxide or oxyhydroxide. Nitrate groups are nevertheless present after impregnation (XPS, IR and TPO). The IR spectra suggest that there are two nitrate species: one bonded to zirconium, the other present as negative counter-ion for the silica surface, which is positively charged in solutions of low $\mathrm{pH}$. Upon heating, the nitrate groups coordinated to zirconium start to decompose and desorb as $\mathrm{NO}_{x}$ at about $150^{\circ} \mathrm{C}$ (TPO, IR). In XPS, the intensity of the nitrate signals decreases by a factor of 2-3 after heating the samples to $200^{\circ} \mathrm{C}$ and goes to zero after heating to $300^{\circ} \mathrm{C}$. The $\mathrm{N}-\mathrm{O}$ vibrations of the nitrate counter-ions of the silica disappear from the IR spectrum after calcination of the catalysts at $300-400^{\circ} \mathrm{C}$.

The zirconium-to-silicon XPS intensity ratio indicates that the initially deposited zirconium phase has characteristic dimensions of the order of a few $\mathrm{nm}$. Upon calcination some loss of dispersion occurs in the catalysts with 16 and $24 \mathrm{wt} . \% \mathrm{ZrO}_{2}$ loading. For temperatures above $300^{\circ} \mathrm{C}$ all samples are more 
or less stable with respect to sintering. The final dispersion of the catalysts is below $10 \%$.

The combination of XPS, SIMS, IR and TPO appears valuable for investigating the genesis of these oxide on oxide systems. The most useful information from XPS in this work is that on the dispersion of the $\mathrm{ZrO}_{2}$ over the support. The XPS binding energies did not give detailed information about the chemical changes in the zirconium compounds on the silica during the calcination procedures. Due to inhomogeneous charging, subtleties in peak positions which can be observed in conducting model systems [7] are lost in the spectra of insulating samples. In future work we intend to exploit the opportunities that these conducting model systems offer for the investigation of catalyst preparation by means of surface spectroscopies.

Chemical state information is provided by the other spectroscopies used in this work: SIMS, IR and TPO. These techniques readily reveal the conversion of the zirconium precursors to the final oxide. TPO monitors the evolution of fragments from decomposed precursors or their oxidation products when they desorb from the surface, as well as the oxygen consumption of the catalyst. IR detects the presence of nitrate, ethoxy or acetate ligands of zirconium on the surface of the catalyst. It is interesting to note that where the data from TPO and IR concern the ligands of zirconium, SIMS gives sensitive information on the zirconium itself. Through comparison with spectra of reference compounds, the SIMS patterns of the $\mathrm{Zr}^{+}, \mathrm{ZrO}^{+}$, and $\mathrm{ZrO}_{2}^{+}$ions reveal the chemical state of the zirconium phases in catalyst.

\section{CONCLUSIONS}

(1) Preparation of $\mathrm{ZrO}_{2} / \mathrm{SiO}_{2}$ catalysts via the reaction between surface hydroxyl groups of the silica and the ligands of the zirconium ethoxide-acetate complexes dissolved in ethanol leads to a catalyst with a dispersion of the order of $75 \%$. Formation of the zirconium oxide from the ethoxide precursor takes place upon calcination at $300-400^{\circ} \mathrm{C}$. The catalysts are rather stable with respect to sintering for temperatures up to at least $700^{\circ} \mathrm{C}$.

(2) Preparation of $\mathrm{ZrO}_{2} / \mathrm{SiO}_{2}$ catalysts by means of incipient wetness impregnation from an aqueous zirconium nitrate solution results in catalysts with dispersions of the order of $10 \%$ or less.

(3) XPS, SIMS, IR and TPO form a useful combination for characterizing these $\mathrm{ZrO}_{2} / \mathrm{SiO}_{2}$ catalysts in different stages of the preparation. XPS gives important information on the dispersion of the $\mathrm{ZrO}_{2}$ phase over the support but provides little chemical information, partly because of charge broadening of the XPS peaks. SIMS, IR and TPO, on the other hand provide detailed information on the transformation of the catalyst precursors to the final $\mathrm{ZrO}_{2}$ phase. 


\section{ACKNOWLEDGEMENT}

We thank Miss T. Ast and Mr. M.C.A.F. van der Leur for their assistance in part of the XPS/SIMS work, Miss L.M. Eshelman for the XPS measurement of the $\mathrm{ZrO}_{2} / \mathrm{SiO}_{2} / \mathrm{Si}$ model system, and Mr. M.J.A.G. Deelen for his assistance with the TPO experiments. Helpful discussions with Prof. J.A.R. van Veen and Prof. R.A. van Santen are gratefully acknowledged. This work was supported in part by grant P 70-154 from the Netherlands Organization for Scientific Research (NWO).

\section{REFERENCES}

1 M-Y. He and J.G. Ekerdt, J. Catal., 90 (1984) 17.

T. Yamaguchi, H. Sasaki and K. Tanabe, Chem. Lett., (1973) 1017.

K. Tanabe, Mater. Chem. Phys., 13 (1985) 347.

T. Yamaguchi, T. Morita, T.M. Salama and K. Tanabe, Catal. Lett., 4 (1990) 1.

T. Lizuka, Y. Tanaka and K. Tanabe, J. Catal., 76 (1982) 1.

6 P.D.L. Mercera, J.G. van Ommen, E.B.M. Doesburg, A.J. Burggraaf and J.R.H. Ross, Appl. Catal., 57 (1990) 127.

7 L.M. Eshelman, A.C.Q.M. Meijers, A.M. de Jong and J.W. Niemantsverdriet, in preparation.

8 C.D. Wagner, W.M. Riggs, L.E. Davis and J.F. Moulder, Handbook of XPS, Perkin-Elmer Corporation, Eden Prairie MN, USA, 1979.

9 H.P.C.E. Kuipers, H.C.E. van Leuven and W.M. Visser, Surf. Interf. Anal., 8 (1986) 235.

10 K. Hirokawa and Y. Danzaki, Surf. Interf. Anal., 4 (1982) 63.

11 B.M. Gatehouse, S.E. Livingstone and R.S. Nyholm, J. Chem. Soc., (1957) 4222.

12 B.M. Gatehouse, S.E. Livingstone and R.S. Nyholm, J. Inorg. Nucl. Chem., 8 (1958) 75.

13 G. Herzberg, Infrared and Raman Spectra of Polyatomic Molecules, Van Nostrand, New York, 1945.

14 Yu. Ya. Kharitonov, L.I. Yuranova, V.E. Plyushchev and V.G. Pervykh, Russ. J. Inorg. Chem., 10 (1965) 399.

15 F.G.R. Gimblett, A. Hussain and K.S.W. Sing, J. Therm. Anal., 34 (1988) 1001.

16 B.E. Yoldas, J. Mater. Sci., 21 (1986) 1080. 